University of Nebraska - Lincoln

DigitalCommons@University of Nebraska - Lincoln

USDA National Wildlife Research Center - Staff Publications
U.S. Department of Agriculture: Animal and Plant Health Inspection Service

June 2002

\title{
Methyl anthranilate aerosol for dispersing birds from the flight lines at Homestead Air Reserve Station
}

Richard M. Engeman

USDA-APHIS-Wildlife Services, s_r100@yahoo.com

Jeffrey Peterla

USDA/APHIS/WS

Bernice Constantin

USDA/APHIS/WS

Follow this and additional works at: https://digitalcommons.unl.edu/icwdm_usdanwrc

Part of the Environmental Sciences Commons

Engeman, Richard M.; Peterla, Jeffrey; and Constantin, Bernice, "Methyl anthranilate aerosol for dispersing birds from the flight lines at Homestead Air Reserve Station" (2002). USDA National Wildlife Research Center - Staff Publications. 482.

https://digitalcommons.unl.edu/icwdm_usdanwrc/482

This Article is brought to you for free and open access by the U.S. Department of Agriculture: Animal and Plant Health Inspection Service at DigitalCommons@University of Nebraska - Lincoln. It has been accepted for inclusion in USDA National Wildlife Research Center - Staff Publications by an authorized administrator of DigitalCommons@University of Nebraska - Lincoln. 
Published by Elsevier Science Ltd.

\title{
Methyl anthranilate aerosol for dispersing birds from the flight lines at Homestead Air Reserve Station
}

\author{
Richard M. Engeman ${ }^{a}$, Jeffrey Peterla ${ }^{\underline{b}}$ and Bernice Constantin $\underline{\underline{b}}$ \\ ${ }^{a}$ National Wildlife Research Center, 4101 LaPorte Ave., Fort Collins, CO 80521-2154, \\ USA \\ ${ }^{\mathrm{b}}$ USDA/APHIS/WS, 2820 East University Ave., Gainesville, FL 32641, USA
}

Available online 7 November 2001.

\begin{abstract}
The failure of traditional hazing methods to provide a lasting dispersal of birds from the flight lines at Homestead Air Reserve Station, Florida led to trials with Rejex-it ${ }^{\circledR}$ TP-40 methyl anthranilate (MA) formulation as an aerosol. A variety of civil, military and other government aircraft use the base, including combat aircraft which are particularly prone to bird airstrikes due to low altitude, high speed flights. Migrating swallows and killdeer congregate at the airfield to forage on insects, and the large numbers of birds cause restrictions in airfield operations because of potential strike hazards with aircraft. MA applied by fogger upwind of the areas to be protected was found to provide a dispersal lasting the remainder of the day. The median time from imposition of airfield restrictions on flight operations to a declaration of a low bird hazard potential was approximately 45 min, and $75 \%$ of applications resulted in removal of airfield restrictions within $1.5 \mathrm{~h}$.
\end{abstract}

Author Keywords: Airport hazards; Bird airstrike; Repellent

Published in International Biodeterioration \& Biodegradation

Volume 49, Issues 2-3, 2002, Pages 175-178 


\title{
Methyl anthranilate aerosol for dispersing birds from the flight lines at Homestead Air Reserve Station
}

\author{
Richard M. Engeman ${ }^{\mathrm{a}, *}$, Jeffrey Peterla ${ }^{\mathrm{b}}$, Bernice Constantin ${ }^{\mathrm{b}}$ \\ ${ }^{a}$ National Wildlife Research Center, 4101 LaPorte Ace., Fort Collins, CO 80521-2154. USA \\ ${ }^{b}$ USDA,APHIS WS, 2820 East Unitersity Are., Gainestille. FL 3264l, USA
}

\begin{abstract}
The failure of traditional hazing methods to provide a lasting dispersal of birds from the flight lines at Homestead Air Reserve Station, Florida led to trials with Rejex-it ${ }^{\mathrm{B}}$ TP-40 methyl anthranilate (MA) formulation as an acrosol. A variety of civil, military and other government aircraft use the base, including combat aircraft which are particularly prone to bird airstrikes due to low altitude, high speed flights. Migrating swallows and killdeer congregate at the airfield to forage on insects, and the large numbers of birds cause restrictions in airfield operations because of potential strike hazards with aircraft. MA applied by fogger upwind of the areas to be protected was found to provide a dispersal lasting the remainder of the day. The median time from imposition of airfield restrictions on flight operations to a declaration of a low bird hazard potential was approximately $45 \mathrm{~min}$, and $75 \%$ of applications resulted in removal of airficld restrictions within 1.5 h. Published by Elsevier Science Ltd.
\end{abstract}

Keyrords: Airport hazards; Bird airstrike; Repellent

\section{Introduction}

Bird strikes with aircraft are a worldwide concern because they threaten passenger safety (Thrope, 1997), result in lost revenue and costly repairs to aircraft (Michael, 1986; Milsom and Horton, 1990; Linnell et al., 1996; Robinson, 1997; Cleary and Dolbeer, 1999; Cleary et al., 1997, 1998), and can erode public confidence in the air transport industry as a whole (Conover et al., 1995). Military flights are particularly vulnerable to bird strikes because they often involve high speeds at the low altitudes where birds are also most active (Blokpoel, 1976).

Hazing and physical barriers have traditionally been used to exclude wildlife from areas (Marsh et al., 1991; Hygnstrom et al., 1994). Airfields present inherent difficulties for these methods, because exclusionary devices obviously cannot be applied for birds along flight lines without excluding aircraft, and wildlife often rapidly habituate to hazing methods, especially if they are applied in a predictable fashion (Allen, 1990).

Repellents offer another option for deterring wildlife entrance into an area. The primary component of syn-

\footnotetext{
${ }^{*}$ Corresponding author. Tel.: +1-970-266-6091; fax: -1-970-2666089 .

E-mail address: richard.m.engeman(ausda.gov (R.M. Engeman).
}

thetic grape flavoring, methyl anthranilate (MA), has been identified to be a powerful avian irritant (Kare, 1961). It has been successfully tested as a topical repellent to deter goose grazing on grass (Cummings et al., 1991), to reduce bird damage to blueberries (Cummings et al., 1995), and to repel birds at landfills and standing water on airports (Dolbeer et al., 1993).

The physiological system that mediates oral detection of irritants also innervates the mucosae of the eyes and nasal passages (Stevens et al., 1998). Aerosol application of chemical irritants for bird management follows the same principle as tear gases used for human crowd control (Yih, 1995; Anderson et al., 1996; Stevens and Clark, 1998), and a strong irritation response by European starlings (Sturnus vulgaris) to aerosol bursts of MA formulations was demonstrated in research trials by Stevens and Clark (1998), with no evidence of habituation. MA fog, applied over multiple nights, has driven starlings and common grackles (Quiscalus quiscula) from roost sites (Vogt, 1997), and airport hangers (Vogt, 1999).

We tested application of a MA formulation by aerosol fogger on Homestead Air Reserve Station as a nonlethal means for dispersing large numbers of birds that accumulate at the airfield during migrations. Previously, hazing had not been effective at producing a lasting bird dispersal from the base for significant portions of the day. Bird conditions have 
often posed unacceptable hazards. and aircraft operations have had to be highly restricted or shut down.

\section{Methods}

\subsection{Homestead Air Reserte Station}

Homestead Air Reserve Station is situated approximately $33 \mathrm{~km}$ southeast of Miami, Florida, and $10 \mathrm{~km}$ east of the city of Homestead, Florida. The base area is flat, with an average elevation of $2.3 \mathrm{~m}$ above mean sca level. The airfield has one runway (NW-SE), and serves military as well as aircraft from the US Customs Miami Air Branch and general aviation. Aircraft using the base range from F-16 and F-15 combat aircraft to small propeller planes to $20-30$ passenger jets. The airfield receives substantial use by fighter aircraft including weapons training deployment and several exercises each ycar involving joint service fighter and mission support aircraft.

The Homestead airfield faces a bird-airstrike hazard that results from large numbers of barn swallows (Hirundo rustica), tree swallows (Tachycineta bicolor) and killdeer (Charadritus vociferus) using the habitat at the airbase during their migrations. The spatial and temporal heterogeneity among species in migration patterns presents a year-round potential for large congregations of birds. These bird species typically do not roost on the base, but arrive in the morning as insects begin hatching, and they carry out low level foraging flights in large numbers (up to several thousand birds). When insects are not active, birds often loaf in large numbers along the runways until hatches begin.

The airfield portion of the base is mowed, but active habitat modification is not applied throughout the base. The base lies between Everglades and Biscayne National Parks, and insecticides are not generally applied for other than mosquitos.

\subsection{Bird watch condition ( $B W C$ )}

As part of standard base operations, bird activity is classified into three BWC categories for rapid dissemination of information, and for implementation of operational procedures (US Air Force, 1999). While size and location of birds are factored into $\mathrm{BWC}$ designations, number of birds has been the primary factor used for swallows and killdeer. BWC-Low is defined as normal bird activity on or above the airfield with a low probability of airstrike hazard. Normal flying operations are authorized under this condition. A BWC-Moderate is defined by increased bird population in locations that increase the potential for a strike. This condition results in substantial restrictions in operations and requires increased vigilance by all agencies, supervisors, and aircrews. Multiple approaches and traffic pattern activity for Air Force Reserve combat aircraft are not permitted. Formation takeoffs, approaches, and landings are prohib- ited. BWC-Severe is defined by high bird populations on or immediately above the active runway, or other locations that represent a high potential for a strike. This condition requires supervisors and aircrews to thoroughly evaluate mission needs before conducting operations under this condition. Takeoff and landing of Air Force Reserve Command aircraft are prohibited.

\subsection{Hazing methods pretiously applied}

A variety of hazing methods had been applied in attempts to disperse the swallows and killdeer. Auditory frightening was conducted with pyrotechnics and propane cannons. Vehicular harassment was conducted along runways and included further auditory frightening with the use of sirens. Base personnel would also walk through runway areas and frighten birds. On occasion, limited shooting of birds was integrated with the other methods. Operational trials with MA were initiated because the hazing methods had been ineffective for lasting bird dispersal. Thus, hazing methods could not justifiably be applied as a basis for comparison with MA when operations and safety were at a premium at the airfield.

\subsection{MA application}

MA applications were made when BWCs due to swallow or killdeer numbers resulted in restricted operations, that is when BWC-Severe or BWC-Moderate conditions existed. Thus, time of MA application was variable according to when a hazard was designated. A commercially available, proprietary formulation of MA, Rejex-it " TP-40 ( $40 \% \mathrm{wt} / \mathrm{wt} \mathrm{MA})$, was applied using a Grizzly fogger (model series 422400, Clark Enginecring Technologies). (Use of product names is strictly for identification purposes and does not imply product endorsement by the authors or USDA.) The equipment was set for an average droplet size of $15 \mu \mathrm{m}$. A 5-10 knot sea brecze was typical at the base, and fogging with MA was done on the upwind side of the airfield so that the MA plume would envelop the areas where birds were to be excluded. MA applications were initiated in the final quarter of 1997 and have continued to the present.

\subsection{Data}

Bird counts were made each day as one of the considerations for imposition of flight restrictions due to swallows and/or killdeer. For the same days, airfield tower records were examined to determine at what times flight restrictions were imposed due to swallow and/or killdeer numbers (BWC-Severe or BWC-Moderate), and at what times those restrictions were lifted (BWC-Low). Because comparative trials could not be conducted at an operational airfield, a descriptive assessment of MA efficacy was made, with the knowledge that the traditional hazing methods had never expeditiously dispersed the swallows and killdeer from the 
Table 1

The days, bird numbers, times flight restrictions were implemented due to birds and the times those restrictions were lifted at Homestead Air Reserve Base, Florida during 2000

\begin{tabular}{llllc}
\hline \multirow{2}{*}{$\begin{array}{l}\text { Date } \\
\text { (in 2000) }\end{array}$} & $\begin{array}{l}\text { Estimated } \\
\text { \# of birds }\end{array}$ & \multicolumn{2}{l}{ Times flight restrictions: } & Minutes \\
\cline { 3 - 4 } & & Implemented & Lifted & \\
\hline 3 May & 300 & $11: 58$ & $12: 34$ & 36 \\
5 May & 450 & $11: 20$ & $12: 40$ & 80 \\
6 May & 600 & $10: 57$ & $11: 14$ & 17 \\
11 May & 400 & $10: 47$ & $11: 35$ & 48 \\
16 May & 300 & $11: 00$ & $11: 24$ & 24 \\
20 May & 250 & $11: 25$ & $12: 05$ & 40 \\
23 May & 450 & $11: 01$ & $11: 40$ & 39 \\
24 May & 300 & $11: 20$ & $12: 01$ & 41 \\
3 Aug & 500 & $12: 43$ & $13: 37$ & 54 \\
5 Aug & 400 & $11: 52$ & $17: 40$ & 348 \\
10 Aug & 500 & $11: 14$ & $13: 57$ & 163 \\
24 Aug & 450 & $11: 22$ & $14: 58$ & 216 \\
Median & 425 & & & 44.5 \\
\hline
\end{tabular}

airfield in the past. Because bird numbers and dispersal times were asymmetrically distributed, nonparametric descriptive statistics were appropriately applied.

\section{Results}

Of the three species, barn swallows occurred most frequently and in the highest numbers, with as many as 4200 barn swallows observed on the airfield. The distribution of the numbers of birds was highly skewed; the median number observed on days where flight restrictions were enacted from 1998 to 2000 was 450 , while the mean for the same days was 864. Unfortunately, tower records specifying the BWCs and the times they were implemented were only available for the year 2000. During 2000, the airfield was subjected to flight restrictions due to high numbers of swallows on 12 days (Table 1). The times at which airfield restrictions were implemented were between 10:45 am and noon for all but one day, where restrictions were implemented at 12:43 pm. MA was applied each day flight restrictions were imposed. The median number of birds at the time airfield restrictions were imposed in 2000 was 425 . The median length of time until BWC-Low was designated for resumption of full operational ability was $44.5 \mathrm{~min}$, and on $75 \%$ of the days BWC-Low resulted within $1.5 \mathrm{~h}$ of designation of restrictions.

\section{Discussion}

MA aerosol has been highly effective at Homestead Air Reserve Station for dispersing large numbers of swallows and killdeer from the flight lines in relatively short periods of time. Traditional hazing methods rely on visual or auditory stimuli, and prior to the use of MA-based aerosols, hazing by traditional methods, including occasional shooting, had never succeeded in producing an effective dispersal of these birds from the airficld.

One interesting observation that aided in preparation for fogging was that 2-3 days in advance to an influx of large numbers of swallows, large numbers of dragonflies (order: Odonata) often would swarm the airfield. While the biological explanation of this phenomena (which we do not offer) might be fascinating, the practicality of the event was that it allowed time to prepare the fogging machinery and insure everything was in working order prior to the immediate need at the airfield.

The gentle sea brecze typical of the area facilitated application with the fogger. Situations without such a breeze, or with higher winds could increase the difficulty in successfully treating an entire area from which birds need to be cxcluded. In those situations, plume modeling software could be a useful tool for designing how application of MA-based acrosol could most efficiently be carried out for delivering adequate quantities for producing an aversive reaction by the target birds (Stevens and Clark, 1998).

Application of MA as an aerosol has been an effective, efficient and practical solution for dispersing large groups of swallows and killdeer from the airficld. Further operational trials are merited for dispersing other species in other airfield circumstances.

\section{Acknowledgements}

K. Fagerstone, M. Fall, D. York, and two anonymous referees provided valuable revicws of earlier versions of the manuscript.

\section{References}

Allen, C.II., 1990. Mitigating impacts to wildtife at FMC Gold Company's Paradise Peak. In: Proceedings Nevada Wildlife Mining workshop. pp. 67-71.

Anderson, P.J., Lau, C.S.N., Taylor. W.R.J., Critchley, J.A.J.H.. 1996. Acute effects of the potent lacrimator o-chlorobenzylidene malononitrile (CS) tear gas. Human Fixperimental Toxicology 15, 461465.

Blokpoel, H., 1976. Bird Hazards to Aircraft. Books Canada Inc.. Buffalo, NY, 236pp.

Cleary, E.C., Dolbeer, R.A., 1999. Wildlite hazard management at airports. Federal Aviation Administration and US Dept. Agriculture Wildlife Services, Washington. DC, 248pp.

Cleary, E.C.. Wright, S.E., Dolbeer, R.A., 1997. Wildlife strikes to civil aircraft in the United States 1992 1996. Report DOT FAA AS 97-3, $30 \mathrm{pp}$.

Cleary, E.C., Wright, S.E., Dolbeer, R.A.. 1998. Wildlife strikes to civil aircraft in the United States 1991 1997. Report DOT FAA AS 98-4. $34 \mathrm{pp}$.

Conover, M.R.. Pitt, W.C.. Kessler, K.K., Dubow, T.J.. Sanborn, W.A., 1995. Review of data on human injuries, illnesses. and economic losses caused by wildlife in the United States. Wildlife Society Bulletin 23, $407-414$.

Cummings, J.L., Mason, J.R.. Otis, D.L., Heisterberg, J.F., 1991. Evaluation of dimethyl and methyl anthranilate as a Canada goose repellent on grass. Wildlife Society Bulletin 19, 184-190. 
Cummings, J.L., Avery, M.L., Pochop, P.A., Davis Jr., J.E., Decker, D.G., Krupa. H.W., Johnson, J.W., 1995. Evaluation of a methyl anthranilate formulation for reducing bird damage to blueberries. Crop Protection $14,257-259$.

Dolbeer, R.A., Belant, J.L.. Clark, L., 1993. Methyl anthranilate formulations to repel birds from water at airports and food at landfills. In: Pierce, R.A., Henderson, F.R. (Eds.), Great Plains Wildlife Damage Control Workshop, Vol. 11, pp. 42-53.

Hygnstrom, S.E., Timm, R.M., Larson, G.E., 1994. Prevention and Control of Wildlife Damage. Univ. Neb Coop Exten, US Dept. Ag., Great Plains Ag Council, Washington, DC.

Kare, M.R., 1961. Bird Repellent. US Patent 2967128.

Linnell, M.A.. Conover, M.R., Ohashi, T.J., 1996. Analysis of bird strikes at a tropical airport. Journal of Wildlife Management 60 , 935-945.

Marsh, R.E., Erickson, W.A., Salmon, T.P., 1991. Bird hazing and frightening devices. University of California, Davis, CA. 233pp.

Michael, R.A., 1986. Keep your eye on the birdie: aircraft engine bird ingestion. Journal of Air Law and Commerce 51, 1007-1035.

Milsom, T.P., Horton, N., 1990. Birdstrike: an assessment of the hazard on UK civil aerodromes from 1976-1990. UK Bird Strike Avoidance Team, $355 \mathrm{pp}$.
Robinson, M., 1997. The potential for significant financial loss resulting from aircraft bird strikes in or around an airport. Bird Strike Committee. Boston, MA, 20pp.

Stevens, G.R., Clark, L.. 1998. Bird repellents: development of avian-specific tear gases for resolution of human-wildlife conflicts. International Biodeterioration \& Biodegradation 42, 153-160.

Stevens, G.R.. Clark, L., Weber, R.A., 1998. The use of aerosol repellents as an avian deterrent strategy. In: Procedings Vertebrate Pest Conference, University of California, Davis, Vol. 18, pp. 74-76.

Thrope, J., 1997. The implications of recent serious bird strike accidents and multiple engine ingestions. Bird Strike Committee, Boston, MA. $11 \mathrm{pp}$.

US Air Force, 1999. Bird activity. Airfield Management, Homestead Air Reserve Station OSA Opcrating Instruction 91-212.

Vogt, P.F., 1997. Control of nuisance birds by fogging with ReJeX-iT TP-40. Proceedings of the Great Plains Wildlife Damage Control Workshop, Vol. 13. pp. 63-66.

Vogt, P.F., 1999. Complete control of nuisance birds in airport hangars. Ottawa, Ontario, Canada, Birdstrike Committee USA/Bird Strike Committee Canada, pp. 155-158.

Yih, J.-P., 1995. CS gas injury to the eye. British Medical Journal 311, 276. 